\title{
Evaluation of canola chlorophyll index and leaf nitrogen under wide range of soil moisture
}

\author{
Fatemeh Meskini-Vishkaee ${ }^{*}$, Mohammad Hossein Mohammadi ${ }^{1}$, Mohammad Reza Neyshabouri ${ }^{2}$, \\ and Farid Shekari ${ }^{3}$ \\ ${ }^{1}$ Department of Soil Science, University of Zanjan, post code 38791-45371, Zanjan, Iran \\ ${ }^{2}$ Department of Soil Science, University of Tabriz, post code 5166616471, Tabriz, Iran \\ ${ }^{3}$ Department of Agronomy and Plant Breeding, University of Zanjan, post code 38791-45371, Zanjan, Iran
}

Received August 31, 2014; accepted December 15, 2014

A b s t r a c t. The paper presents a study on the effect of soil matric suction on the variation of leaf chlorophyll index and nitrogen concentration of canola. Results showed that chlorophyll index increases exponentially with soil matric suction, especially at the late season of canola growing time. At moderate matric suction (200 and $300 \mathrm{kPa}$ soil suction heads), chlorophyll index remains nearly constant, but in drier soil (matric suction $>300 \mathrm{kPa}$ ), chlorophyll index increases gradually with time. Despite the variation of the total leaf nitrogen with the soil matric suction, it is similar to the variation of the chlorophyll index, but the results showed that the chlorophyll index - nitrogen concentration curve has a demarcated bi-modal shape. We suggest that $2.7 \%$ of nitrogen and 69.8 of the chlorophyll index value represent the upper limit of the chlorophyll meter reliability for estimation of canola nitrogen under a wide range of soil moisture levels. These results confirm that the chlorophyll meter can be used as an effective tool for rapid and non-destructive estimation of the relative chlorophyll and nitrogen content in canola leaves at a wide range of soil moisture content, except for nearly wilting coefficient or extremely high drought stress.

K e y w o r d s: chlorophyll index, crop demand-driven realtime $\mathrm{N}$ management, soil moisture, stress

\section{INTRODUCTION}

To tolerate many environmental stresses, plants set a plethora of adaptation mechanisms, from early responses to longer term metabolic and physiognomic alterations (Gunes et al., 2006). Water shortage stress is one of the most important abiotic stress factors which seriously limits plant growth and field crops production, more than any other environmental stresses.

\footnotetext{
*Corresponding author e-mail: fatemeh.meskini@znu.ac.ir
}

Since the plant leaf is the one of the most responsive organs to environmental conditions, the symptoms of environmental stress are exhibited more clearly than in the case of the stem and the roots. Considering that the chlorophyll content of leaf is a primary requisite for plant photosynthesises (Arjenaki et al., 2012), consequently, its shortage can result in many crises, such as chlorosis, reduction in growth rate and crop yield.

The variation of chlorophyll content under drought stress is studied by many researchers. For instance, Jaleel et al. (2008) showed that under the drought stress plant growth can be limited, with variation of chlorophyll content (or photosynthesis), respiration and nutrient metabolism. On the other hand, Mensah et al. (2006) found that a slight drought stress increases the leaf chlorophyll content in sesame, however any additional stress does not change it anymore. The effects of drought stress on plant growth depend on the plant species, plant growth stage, the stress intensity (soil matric suction) and duration, and finally on the soil hydraulic properties (Mittler and Blumwald, 2010).

Since leaf chloroplasts contain about $70 \%$ of the leaf nitrogen $(\mathrm{N})$, the leaf chlorophyll and $\mathrm{N}$ contents are closely correlated (Wood et al., 1992). Since plant growth reflects the total $\mathrm{N}$ supply from all sources, the plant $\mathrm{N}$ status can be considered as an indicator of the soil $\mathrm{N}$ availability (Varinderpal-Singh et al., 2010). An easily available instrument, the chlorophyll meter (eg SPAD-502 chlorophyll meter), is used widely to evaluate the plant chlorophyll content and, hence, to estimate the plant $\mathrm{N}$ status and deficiencies and, subsequently, to determine the real-time based need for $\mathrm{N}$ fertiliser with introducing a proper calibration

(C) 2015 Institute of Agrophysics, Polish Academy of Sciences 
(Jifon et al., 2005). Experimental relationships between $\mathrm{N}$ concentration and SPAD reading values are expressed with linear (Chang and Robison, 2003) or curvilinear (Dwyer et al., 1995) models depending on the crops, the species, the cultivars and the crop growth stage (Esfahani et al., 2008). In addition, any biotic (eg pests, diseases, weeds) and abiotic stresses (eg drought, heat, cold, salinity) may influence the SPAD reading values and, subsequently, the chlorophyll or $\mathrm{N}$ estimates (Balasubramanian et al., 2000). Thus, it would be convenient to develop a specified functional relationship between the SPAD values and leaf $\mathrm{N}$ contents to improve the accuracy of interpretation of the SPAD value (Balasubramanian et al., 2000; Van den Berg and Parkins, 2004).

Despite many studies performed on plant leaf chlorophyll, the soil hydro-physical properties and the range of matric suction of the experimented soils were not reported, and thus an apparent inconsistency between the results may be suspected due to the limited and incomparable range of soil moisture conditions. Based on our knowledge, there are a few studies relating quantitatively the variation of the chlorophyll content and plant nitrogen to the soil matric suction and hydro-physical properties (Boutraa, 2010).

Therefore, the objectives of this study are:

- to study the effect of a wide range of soil matric suction on the variation of the leaf chlorophyll content of canola measured with the use of a SPAD-502 chlorophyll meter at different plant growth stages, and

- to evaluate the reliable range of the SPAD-502 for the estimation of canola $\mathrm{N}$ concentration under different soil moisture conditions.

\section{MATERIALS AND METHODS}

The variation of canola leaf chlorophyll and nitrogen content under a wide range of controlled soil moisture content in the greenhouse conditions was studied in a completely random blocks design experiment with 3 replicates and 14 soil moisture treatments including 2, 4, 6, 8, 11, 30, 50, 200, $300,500,800,1000,1500$ and $2000 \mathrm{kPa}$ of matric suction heads. Plastic pots ( $0.27 \mathrm{~m}$ height, $0.26 \mathrm{~m}$ internal diameter) were filled with dried and sieved $(0.008 \mathrm{~m})$ soil material with volume of $0.011 \mathrm{~m}^{3}$ and weight of $17.2 \mathrm{~kg}$, collected from the Ap horizon of an agricultural sandy loam soil common in Zanjan, Iran. The pots were packed with the aid of a vibrator to reach the same bulk density as for the undisturbed soil in the field (Table 1). Ten canola seeds were planted in each plastic pot. Once the seeds germinated and emerged, three plants were kept on which the trial was continued. Soil moisture treatments were begun after the plant establishment stage, using:

- homemade tension tables (tensiometers) for 2 to $11 \mathrm{kPa}$ of matric suction heads,

- tensiometers for 30 and $50 \mathrm{kPa}$ of matric suction heads,

- gypsum blocks for 200 to $2000 \mathrm{kPa}$ of matric suction heads.

The 'hanging water principle' was used to apply suction $(2-11 \mathrm{kPa})$ to the pot soils. The difference in height between the water filled in the bottle (as the suction regulator) and the middle of the soil surrounding the porous cap determines the amount of matric suction (Fig 1). The suction regulator was adjusted to apply the required matric suction to the soil samples. The soils reached equilibrium at a specific suction head shortly after each irrigation event and remained constant afterwards. The excess water under each soil suction head was drained through the tube and collected in the suction regulator while the influent and effluent water was measured on a daily basis to calculate total water use.

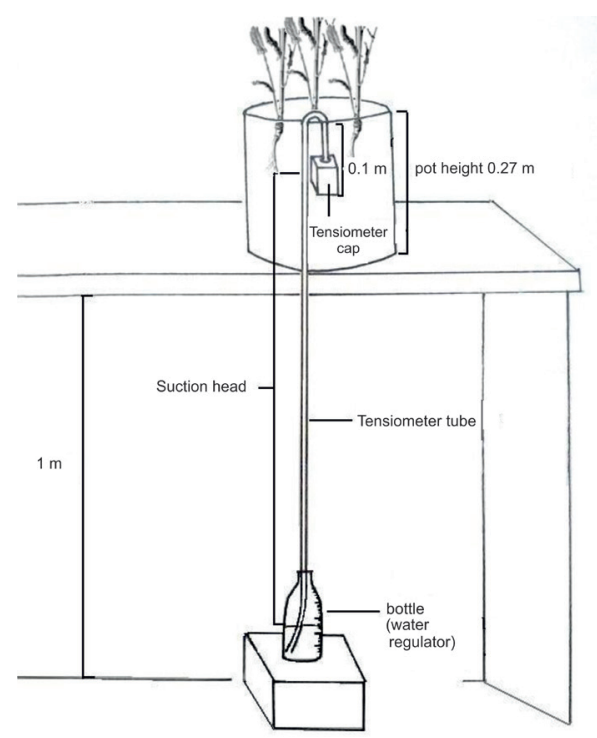

Fig. 1. Schematic of the homemade tensiometer and its functioning as a matric suction regulator.

T a b l e 1. Some soil properties

\begin{tabular}{ccccccccc}
\hline \multicolumn{3}{c}{ Physical properties } & \multicolumn{3}{c}{ Chemical properties } \\
\hline $\begin{array}{c}\text { Sand } \\
(\%)\end{array}$ & $\begin{array}{c}\text { Silt } \\
(\%)\end{array}$ & $\begin{array}{c}\text { Clay } \\
(\%)\end{array}$ & $\begin{array}{c}\text { Porosity } \\
\left(\mathrm{m}^{3} \mathrm{~m}^{-3}\right)\end{array}$ & $\begin{array}{c}\text { Bulk density } \\
\left(\mathrm{Mg} \mathrm{m}^{-3}\right)\end{array}$ & $\begin{array}{c}\mathrm{K} \\
\left(\mathrm{mg} \mathrm{kg}^{-1}\right)\end{array}$ & $\begin{array}{c}\mathrm{P} \\
\left(\mathrm{mg} \mathrm{kg}^{-1}\right)\end{array}$ & $\begin{array}{c}\mathrm{N} \\
(\%)\end{array}$ & $\begin{array}{c}\text { Organic } \\
\mathrm{matter}^{(\%)}\end{array}$ \\
\hline 71 & 15 & 14 & 0.42 & 1.50 & 424.7 & 13.5 & 0.12 & 1.3 \\
\hline
\end{tabular}


For high matric suction $(\mathrm{h} \geq 200 \mathrm{kPa})$ treatment: as the water treatment begun, the matric suction was monitored until the required value was reached. This time course elapsed quickly. After that, to maintain the matric suctions steady, we compensated daily plant water uptake via measurement of soil water content by gypsum blocks. The gypsum blocks data were converted to the soil matric suction and water content using a calibration curve obtained experimentally. The tensiometers and gypsum blocks were installed in the centre of each pot, $0.1 \mathrm{~m}$ below the soil surface.

During the experiment period, supplemental incandescent lighting was provided to extend the day length to $14 \mathrm{~h}$ with 154 to $196 \mu \mathrm{mol} \mathrm{s}^{-1} \mathrm{~m}^{-2}$ of photosynthesis active radiation (PAR), while the night and day air temperature was maintained about 289.15-291.15 and 295.15-299.15 K, respectively. This experiment was conducted from October, 2012, to March, 2013, and repeated from October, 2013, to March, 2014, under greenhouse conditions at the University of Zanjan, Iran ( $36^{\circ} 41^{\prime} \mathrm{N} 48^{\circ} 24^{\prime} \mathrm{E}$, altitude $\left.1651 \mathrm{~m}\right)$.

The soil moisture characteristics curve (SMC) of the used sandy loam soil are shown in Fig. 2. The SMC was obtained using a hanging water column $(0.1-15 \mathrm{kPa})$, pressure plate $(30-100 \mathrm{kPa})$, and pressure membrane apparatus (100-1500 kPa) (Dane and Hopmans, 2002). The soil PSD was determined using a hydrometer and the sieving method (Gee and Or, 2002). Some physical and chemical properties of the soil used are shown in Table 1. Based on soil test, the complementary requirement of essential elements was supplied with splash method at three different growth stages of the plant.

The Minolta SPAD-502 chlorophyll meter was used to acquire a rapid estimate of leaf chlorophyll content index (CCI) (Van den Berg and Parkins, 2004). The measurements were taken on the second leaf which was fully matured. Six measurements were taken per pot (two measurements per plant). The results were then averaged to result in a single value to represent the pot at each stage. To access the effect

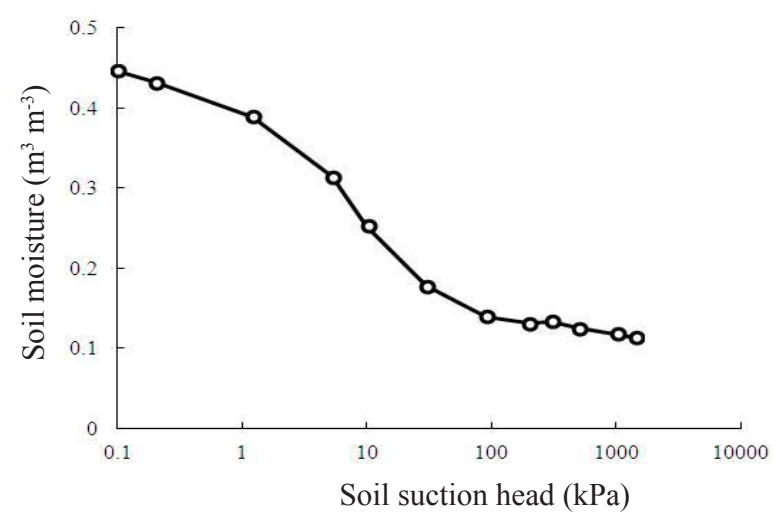

Fig. 2. Soil moisture characteristic curve of the soil used in greenhouse experiment. The moisture contents of low suction heads are given on the top of each point. of drought stress duration on the leaf chlorophyll content reasonably, the results were presented for five life times; 30 , 40, 50, 60 and 65 days after water treatments application.

At the end of the growing stage, plant shoots and grains were harvested separately. All samples were oven-dried at $343.15 \mathrm{~K}$ for at least $72 \mathrm{~h}$ and then weighted. The plant nitrogen concentration was determined by digesting the samples in sulphuric acid $\left(\mathrm{H}_{2} \mathrm{SO}_{4}\right)$ followed by analysis of total $\mathrm{N}$ by the Kjeldahl method (Bremner and Mulvaney, 1982).

A one-way analysis of variance (ANOVA) and Duncan test $(p<0.05)$ were used to analyze the effects of water availability on the leaf chlorophyll content of canola plants.

\section{RESULTS AND DISCUSSION}

The variation of measured shoot dry weight (SDW) as a function of the soil suction heads is shown in Fig. 3. The SDW curve has a demarcated uni-modal bell shape. The first part starts with a relatively low SDW (about $0.04 \mathrm{~kg}$ ) at $2 \mathrm{kPa}$ matric suction, and then slightly increases to $0.066 \mathrm{~kg}$ at $7 \mathrm{kPa}$ matric suction. This part of the curve starts when the increase of soil respiration rate as well as the soil matric suction become more pronounced. The first part of the curve may correspond to a restriction of soil respiration rate (oxygen deficit) which controls the root water uptake at high soil moisture content (low soil matric suction heads) (Mohammadi et al., 2010). However, the oxygen consumption rate or the oxygen transport to the plant root depends on many abiotic and biotic conditions (eg soil temperature, soil texture, plant growth stage and microbial activity), but the soil moisture content (air filled porosity) controls mainly the gas exchange between the root and the air (Feddes et al., 1978). Since the soil drainage enhances the connectivity of the air filled pores, this restriction becomes less at high matric suction heads. The second part of the curve starts from $6 \mathrm{kPa}$ matric suction (maximum yield) onwards, where the SDW drastically decreases. This part may correspond to soil water shortage due to high matric suction head, which restricts the uptake

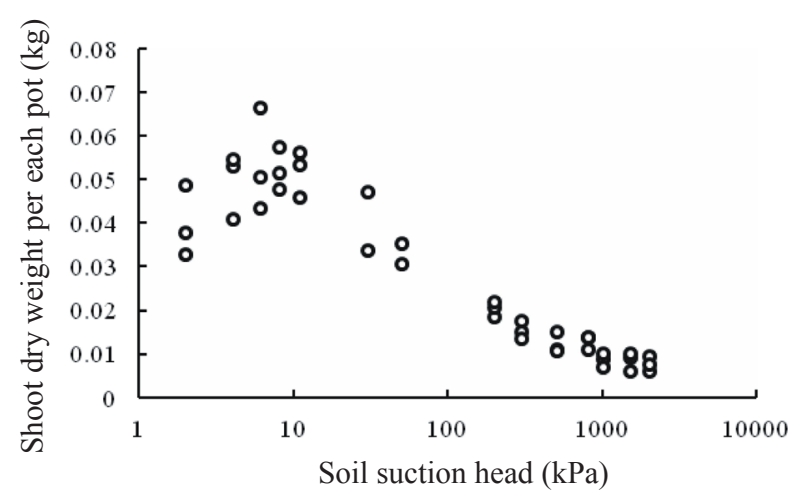

Fig. 3. Measured dry mass of canola shoot (SDW) as a function of the soil matric suction head for the sandy loam soil at greenhouse conditions. 
of water by plant root and subsequently reduces the shoot dry weight (Fig. 3). The shoot is affected by the drought stress. In response to drought stress, plants generally regulate the number and area of leaves to decrease the water demand (Schuppler et al., 1998).

As expected, by the time of imposing the water treatments, the CCI values are about 30 for all plants and there is no significant difference between CCI of plants growing under different soil moisture conditions (Fig. 4a). As the treatments start, the CCI values increase exponentially with the soil matric suction, $\mathrm{h}$, especially at the late season of canola growing time (Fig. $4 \mathrm{~b}-\mathrm{f}$ ). The slope and the intercept of the relationship between the log-transformed $h$ and CCI increase with the duration of the water treatments. This variation can confirm the pronounced effect of soil moisture conditions on the canola CCI. The minimum CCI was

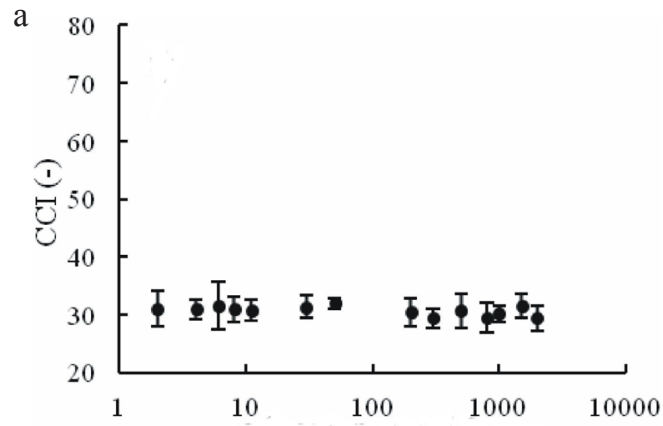

C

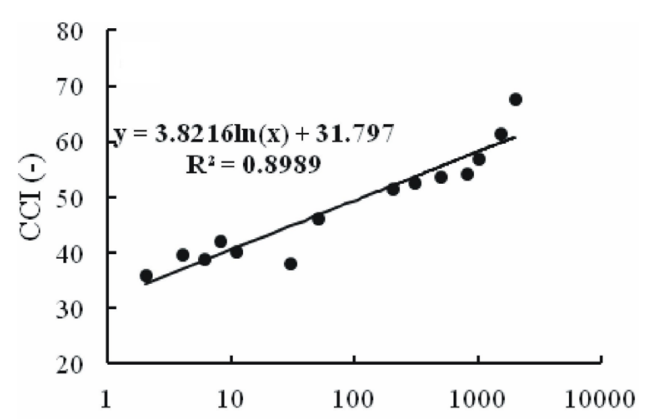

e

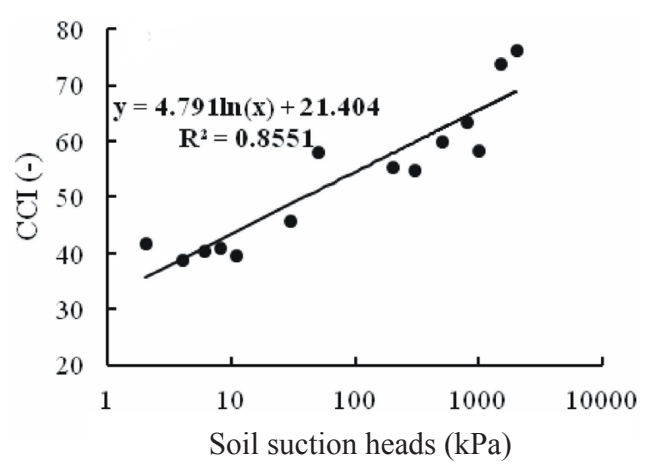

observed for the lowest soil suction heads. The small value of CCI at the high soil moisture content can be attributed to soil oxygen shortage, leaching of soil $\mathrm{N}$ (Nishihara et $a l ., 2001)$, and finally to the enhanced denitrification rate (Valé et al., 2007). The eventual effects of these mechanisms are further evaluated. Since there is no significant difference between the CCI for canola planted at low soil suction heads (2 to $11 \mathrm{kPa}$ ) (results of statistical analysis not shown) and, moreover, since the aeration conditions between these soil suction heads are completely different (Fig. 2), we argue that the canola CCI is not influenced largely by the respiration stress or soil oxygen shortage.

Fig. 5a-d shows that there is no significant difference between the CCI of canola grown at low soil suction heads (less than $50 \mathrm{kPa}$ ), while under higher soil suction heads $(>200 \mathrm{kPa})$, the canola CCI increases significantly with

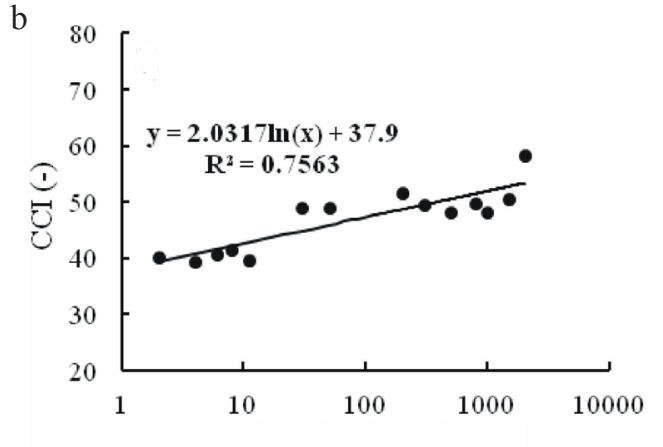

d
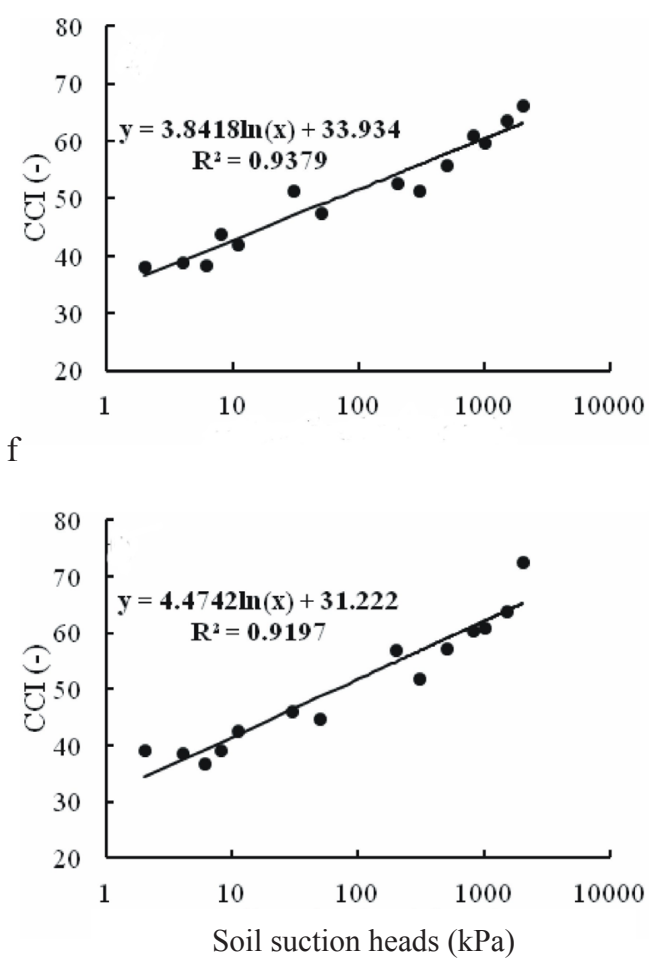

Fig. 4. CCI of canola as a function of soil suction heads at different growing stages: $a-0, b-30, c-40, d-50$, e -60 and $f-65$ days after treatment imposing, respectively. 
a

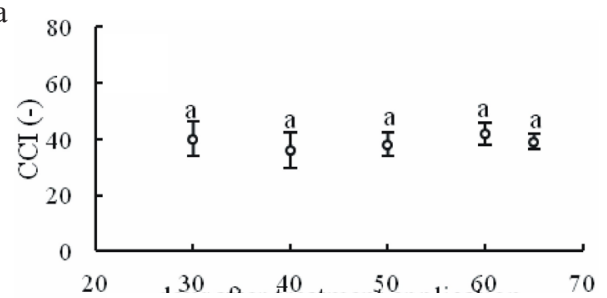

c
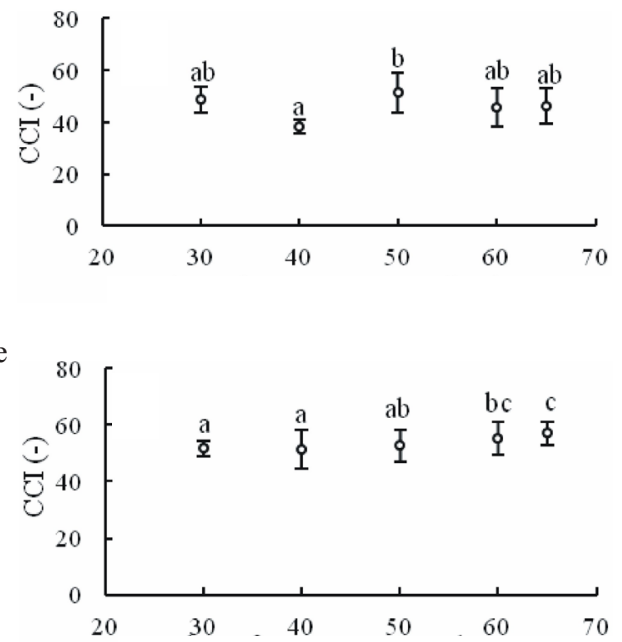

g
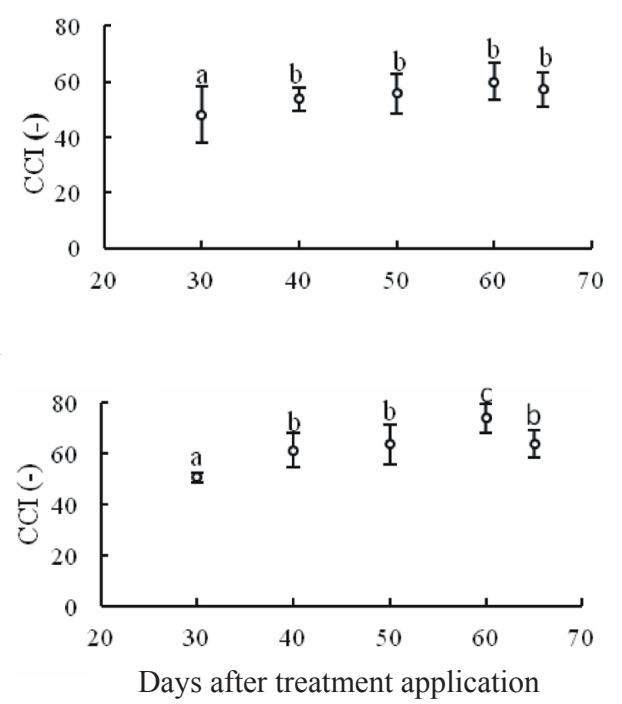

b

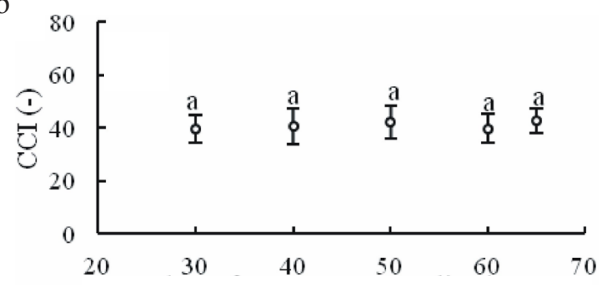

$\mathrm{d}$

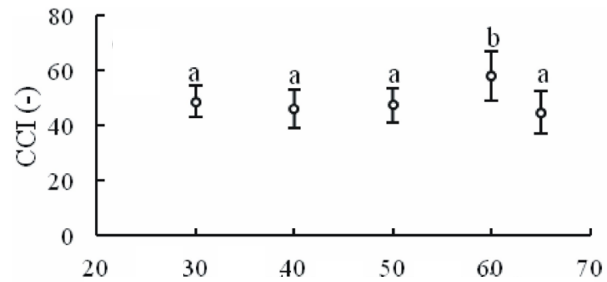

f

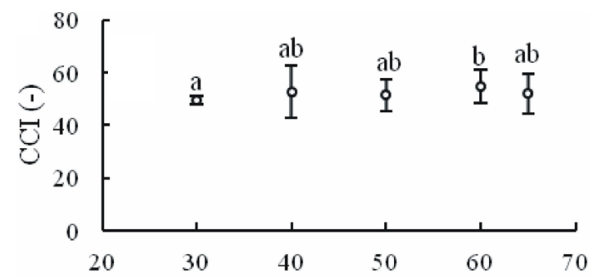

$\mathrm{h}$
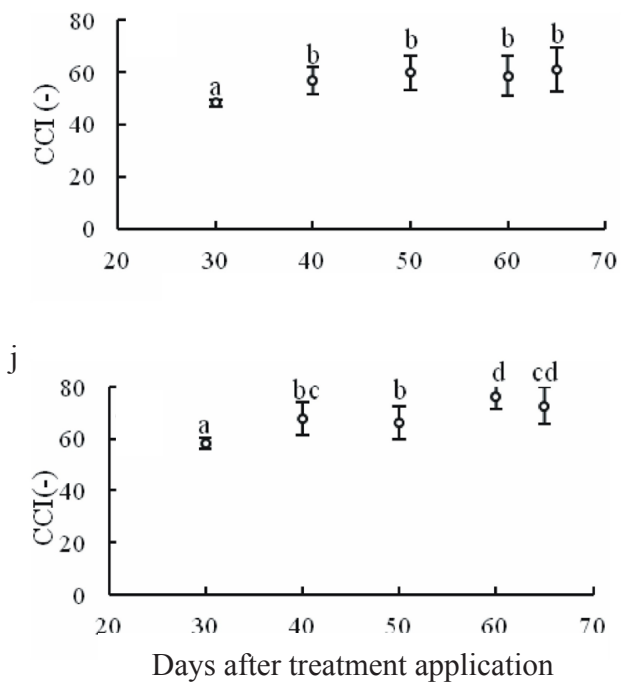

Fig. 5. CCI as a function of time course for the different soil suction treatments. Water treatment at: $a-2, b-11, c-30, d-50, e-200$, $\mathrm{f}-300, \mathrm{~g}-500, \mathrm{~h}-1000, \mathrm{i}-1500, \mathrm{j}-2000 \mathrm{kPa}$ soil suction heads). Different letters on the points indicate significant differences $(\mathrm{p}<0.05)$ between the CCIs. Error bars indicate \pm standard deviation $(\mathrm{n}=18)$.

time course of water treatment (Fig. 5e-j). However, for the canola grown at moderate water stress (200 and $300 \mathrm{kPa}$ soil suction heads), the CCI increases in the later stage of plant growth (60 days after imposing the water treatment) (Fig. 5e and f), but the variation of the CCI starts earlier (40 days after the treatment start) under severe drought stress (higher soil suction heads) (Fig. 5h-j). Cell elongation of the higher plants can be retarded by restriction of water flow from the xylem to the surrounding elongating cells (Nonami, 1998). Impaired mitosis, limited cell elongation and expansion result in reduced plant height, leaf area and the crop yield of plants growing under drought 
stress. Therefore, the increased chlorophyll content under drought stress may be related to a decrease in the leaf area (Rahbarian et al., 2011).

Figure 6 shows that the concentration of leaf $\mathrm{N}$ remains nearly constant from $2 \mathrm{kPa}$ suction head up to $200 \mathrm{kPa}$ suction head. We can argue that eventual $\mathrm{N}$ loss mechanisms in wet soils (eg N leaching, denitrification, respiration stress) did not influence $\mathrm{N}$ uptake by canola. At the high matric suction ( $>300$ onward), the concentration of the leaf $\mathrm{N}$ was raised pronouncedly (Fig. 6).

Since the variation of total leaf $\mathrm{N}$ with the soil moisture regime is similar to the variation of the $\mathrm{CCI}$ in same conditions (Figs 5 and 6), we examined a potential experimental relationship between the leaf $\mathrm{N}$ and the $\mathrm{CCI}$ and we found a strong significant curve linear relation $\left(\mathrm{R}^{2}=0.64\right)$ and its validity range (Fig. 7). Figure 7 shows that the relation between CCI and canola leaf nitrogen concentration curve has a demarcated bi-modal shape. The first part starts with a low CCI (33.8) at $0.61 \% \mathrm{~N}$ which exponentially increases to 69.8 at $2.7 \%$. The second part starts from $2.7 \% \mathrm{~N}$ and then remains nearly constant, ie the SPAD reading value is not affected by the leaf $\mathrm{N}$ where the concentration of $\mathrm{N}$ is higher than $2.7 \%$.

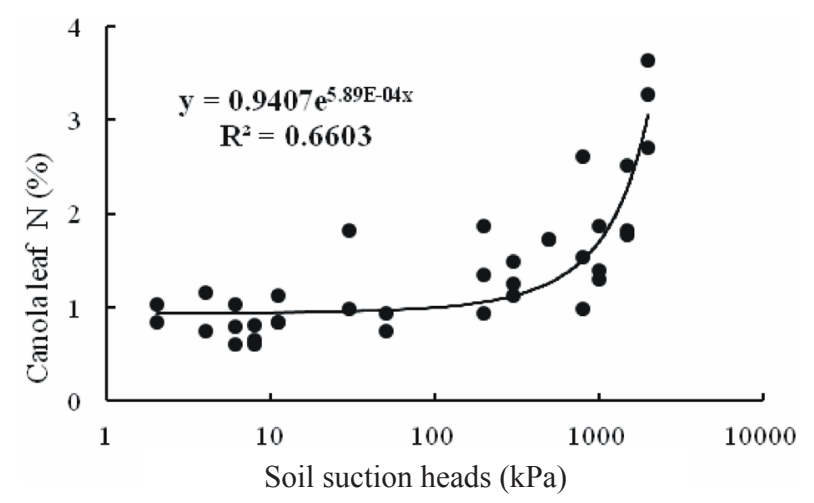

Fig. 6. Variations of canola leaf nitrogen (\%) at the end of growing season as a function of soil suction heads.

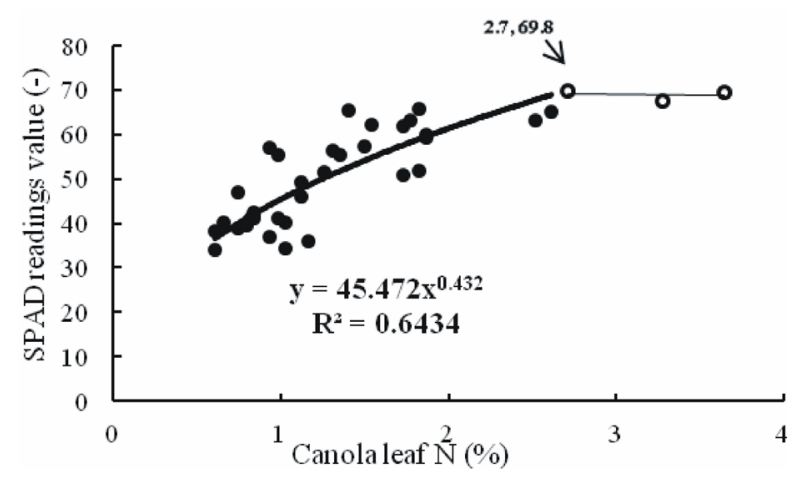

Fig. 7. Variation of SPAD readings as a function of canola leaf $\mathrm{N}$ content. The black smooth line is the best line (corresponding to the filled circle markers) and the black straight line is the plateau part of the curve (corresponding to the empty circle markers).
A close relationship between chlorophyll and nitrogen content is reasonable, because nitrogen is a structural element of chlorophyll and protein molecules, and therefore affects the formation of chloroplasts and accumulation of chlorophyll in them (Daughtry et al., 2000). Moreover, the leaf $\mathrm{N}$ content can influence the monochromatic light reflex-absorb pattern which is related to SPAD reading values (Takebe et al., 1990). In the present study, we also visually observed the darker green colour of leaves of canola plants grown at higher soil suction heads.

Further correlation analysis shows that $65.76 \%$ of the variation of the leaf $\mathrm{N}$ content could be estimated with the SPAD reading values $(r=0.811, p<0.01)$. Variation of the leaf position (Neilsen et al., 1995), the time of sampling (Loh et al., 2002) and the leaf thickness (Jifon et al., 2005) are suspected factors influencing the relationship between the SPAD reading values and the leaf $\mathrm{N}$ content. Indeed, this relationship can be improved by calculating the specific leaf weight or considering the leaf $\mathrm{N}$ content per the leaf area unit (Chang and Robison, 2003).

Figure 7 shows that as the leaf nitrogen concentration increases, the sensitivity of the SPAD to detect leaf $\mathrm{N}$ content decreases. This result is consistent with the observations reported by Dwyer et al. (1995) and Wood et al. (1992). Van don Berg and Perkins (2004) also observed that the accuracy of the portable chlorophyll meters decreases at high readings values. We suggest that this value $(2.7 \% \mathrm{~N}$, 69.8 chlorophyll meter reading) represents the upper limit of the chlorophyll meter reliability to estimate canola $\mathrm{N}$ concentration under a wide range of soil moisture conditions (form very wet to very dry).

The curvilinear response of the SPAD values to canola $\mathrm{N}$ concentration may be attributed to:

- increase in the proportion of nitrate- $\mathrm{N}$ in the total $\mathrm{N}$ form at high $\mathrm{N}$ levels, which is included in assays of total $\mathrm{N}$, whereas, it is not detected by the chlorophyll meter (Dwyer et al., 1995), and

- the effect of drought stress which partially increases the leaf vacuolar pigments affecting the SPAD values (Schepers et al., 1996).

The reduced cell turgor induced by drought stress influences the leaf intercellular spaces and, subsequently, the transmittance of near-infrared light through the leaf tissue, because the SPAD reading value is the leaf transmittance for the red and near infrared radiation spectrum (650 and $940 \mathrm{~nm}$ ). Therefore, the SPAD meter may underestimate chlorophyll content and subsequent $\mathrm{N}$ content at drought stress (Schlemmer et al., 2005). This attribute partially reveals why the SPAD underestimates the high $\mathrm{N}$ levels which occur under severe drought stress.

Since the plant $\mathrm{N}$ was measured at the end of canola growth season (65 days after the treatment application), a smaller proportion of the data was in the plateau part of the curve (Fig. 7), because at later plant growth stages a larger proportion of the leaf $\mathrm{N}$ is eventually associated 
with the chloroplasts, and there is less nitrate- $\mathrm{N}$ in the leaves (Dwyer et al., 1995). Similar results are reported by investigators who studied the relationship between chlorophyll meter readings and plant $\mathrm{N}$ concentration at different plant growth stages (Wood et al., 1992).

In this study, a wide range of canola $\mathrm{N}(0.61-3.64 \%)$ corresponded to the SPAD reading at a wide range of soil moisture conditions (2-2 $000 \mathrm{kPa}$ matric suction). Thus, it is probably appropriate to conclude that the SPAD readings provide a reasonable approximation of the total $\mathrm{N}$ except at a drought stress (more than $1500 \mathrm{kPa}$ soil suction head). So, the chlorophyll meter can be used to estimate the real-time based $\mathrm{N}$ fertilizer need with the aim to decrease insect pest incidence to plants and, possibly, to reduce gaseous emission of nitrous oxide and harmful effects on the groundwater (Varinderpal-Singh et al., 2010).

Since the objectives of this study were to evaluate the variation of the chlorophyll index, measured by the portable chlorophyll meter, and plant nitrogen content under a wide range of soil moisture conditions, the relationship between the CCI and measured leaf chlorophyll content was not considered.

\section{CONCLUSIONS}

From the analysis of the variation of the SPAD reading value (as an index of chlorophyll) and $\mathrm{N}$ content of canola leaf under a wide range of controlled soil moisture content (from nearly saturated soil to very dry soil) it was found that:

1. Regardless of the SPAD reading value and the $\mathrm{N}$ content increase with the soil matric suction head, their relationship follows a curvilinear model with a plateau at high $\mathrm{N}$ content.

2. The SPAD is an effective tool for rapid and nondestructive estimation of the relative chlorophyll and $\mathrm{N}$ content in canola leaves. Once general relationships are established for a particular species, it should be possible to use the chlorophyll meter as a tool for a variety of management and research applications for which precise chlorophyll or nitrogen values are not required, including the assessment of relative health status, physiological changes over time and delineating the effects of management practices such as fertilization.

3. Under drought stress, the use of the SPAD to estimate canola leaf $\mathrm{N}$ content may be accompanied by some uncertainties.

\section{REFERENCES}

Arjenaki F.G., Jabbari R., and Morshedi A., 2012. Evaluation of drought dtress on relative water content, chlorophyll content and mineral elements of wheat (Triticum aestivum L.) varieties. Int. J. Agric. Crop. Sci., 4, 726-729.
Balasubramanian V., Morales A.C., Cruz R.T., Thiyagarajan T.M., Nagarajan R., Babu M., Abdulrachman S., and Hai L.H., 2000. Adaptation of the chlorophyll meter (SPAD) technology for real-time $\mathrm{N}$ management in rice: a review. Int. Rice. Res. Inst., 5, 25-26.

Boutraa T., 2010. Effect of water stress on root growth, water use efficiency, leaf area and chlorophyll content in the desert shurb calotropisprocera. J. Int. Environ. Appl. Sci., 5(1), 124-132.

Bremner J.M. and Mulvaney C.S., 1982. Nitrogen-total. In: Methods of Soil Analysis: Part 2 Chemical and Microbiological Properties. Agron. Monograph, 595-624.

Chang S.X. and Robison D.S., 2003. Nondestructive and rapid estimation of hardwood foliar nitrogen status using the SPAD-502 chlorophyll meter. Forest Ecol. Manag., 181, 331-338.

Dane J.H. and Hopmans J., 2002. Water retention and storage. In: Methods of Soil Analysis. Part 4 Physical Methods. SSSA Book Series, Madison, USA.

Daughtry C.S.T., Walthall C.I., Kim M.S., Brown L., de Colstoun E., and Mcmurtey J.E., 2000. Estimating corn leaf chlorophyll concentration from leaf and canopy reflectance. Remote Sensing Environ., 74, 229-239.

Dwyer L.M., Anderson A.M., Ma B.L., Stewart D.W., Tollenar M., and Gregorich E., 1995. Quantifying the nonlinearity in chlorophyll content meter response to corn leaf nitrogen concentration. Canadian J. Plant Sci., 75, 179-182.

Esfahani M., Ali Abbasi H.R., Rabiei B., and Kavousi M., 2008. Improvement of nitrogen management in rice paddy fields using chlorophyll meter (SPAD). Paddy Water Environ., 6, 181-188.

Feddes R.A., Kowalik P.J., and Zaradny H., 1978. Simulation of filed water use and crop yield. Simulation Monographs, Pudoc, Wageningen, The Netherlands.

Gee G.W. and Or D., 2002. Particle-size analysis. In: Methods of Soil Analysis. Part 4 Physical Methods. SSSA Book Series, Madison, USA.

Gunes A., Cicek N., Ina A., Alpaslan M., Eraslan F., Guneri E., and Guzelordu T., 2006. Genotypic response of chickpea (Cicerarietinum L.) cultivars to drought stress implemented at pre- and postanthesis stages and its relations with nutrient uptake and efficiency. Plant Soil Environ., 52, 368-376.

Jaleel C.A., Manivannan P., Lakshmanan G.M.A., Gomathinayagam M., and Panneerselvam R., 2008. Alterations in morphological parameters and photosynthetic pigment responses of Catharanthusroseus under soil water deficits. Colloids Surfaces: Biointerfaces, 61, 298-303.

Jifon J.L., Syvertsen J. P., and Whaley E., 2005. Growth environment and leaf anatomy affect nondestructive estimates of chlorophyll and nitrogen in Citrus sp. leaves. J. Am. Soc. Hor. Sci., 130, 152-158.

Loh F.C.W., Grabosky J.C., and Bassuk N.L., 2002. Using the SPAD-502 meter to assess chlorophyll and nitrogen content of benjamin fig and cottonwood leaves. HortSci., 12, 683-686.

Mensah J.K., Obadoni B.O., Eroutor P.G., and OnomeIrieguna F., 2006. Simulated flooding and drought effects on germination, growth and yield parameters of sesame (Sesamum indicum L.). African J. Biotechnol., 5, 1249-1253. 
Mittler R. and Blumwald E., 2010. Genetic engineering for modern agriculture: challenges and perspectives. Annual Review Plant Biol., 61, 443-462.

Mohammadi M.H., Asadzadeh F., and Vanclooster M., 2010. Refining and unifying the upper limits of the least limiting water range using soil and plant properties. Plant Soil, 341, 241-256.

Neilsen D., Hogue J., Neilsen G., and Parchomchuk P., 1995. Using SPAD-502 values to assess the nitrogen status of apple trees. HortSci., 30, 508-512.

Nishihara E., Inoue M., Kondo K., Takahashi K., and Nakata N., 2001. Spinach yield and nutritional quality affected by controlled soil water matric head. Agric. Water Manag., 51, 217-229.

Nonami H., 1998. Plant water relations and control of cell elongation at low water potentials. J. Plant Res., 111, 373-382.

Rahbarian R., Khavari-Nejad R., Ganjeali A., Bagheri A., and Najafi F., 2011. Drought stress effects on photosynthesis, chlorophyll fluorsence and water relations in tolerant and susceptible chickpea (Cicer arietinum L.) genotypes. Acta Biologica Cracoviesia Series Botanica, 53, 47-56.

Schepers J.S., Blackmer T.M., Wilhelm W.W., and Resende M., 1996. Transmittance and reflectance measurements of corn leaves from plants with different nitrogen and water supply. J. Plant Physiol., 148, 523-529.
Schlemmer M.R., Francis D.D., Shanahan J.F., and Schepers J.S., 2005. Remotely measuring chlorophyll content in corn leaves with differing nitrogen levels and relative water content. Agronomy Horticulture, Faculty Publications.

Schuppler U., He P.H., John P.C.L., and Munns R., 1998. Effects of water stress on cell division and cell-divisioncycle-2-like cell-cycle kinase activity in wheat leaves. Plant Physiol., 117, 667-678.

Takebe M., Yoneyama T., Inada K., and Murakami T., 1990. Spectral reflectance ratio of rice canopy for estimating crop nitrogen status. Plant Soil, 122, 295-297.

Valé M., Mary B., and Justes E., 2007. Irrigation practices may affect denitrification more than nitrogen mineralization in warm climatic conditions. Biol. Fertility Soils, 43, 641-651.

Van den Berg A.K. and Parkins T.D., 2004. Evaluation of a portable chlorophyll meter to estimate chlorophyll and nitrogen contents in sugar maple (Acer saccharum Marsh.) leaves. Forest Ecol. Manag., 200, 113-117.

Varinderpal-Singh Bijay-Singh, Yadvinder-Singh, Thind H.S., and Gupta R.K., 2010. Need based nitrogen management using the chlorophyll meter and leaf colour chart in rice and wheat in South Asia: a review. NutrCyclAgroecosys., 88, 361-380.

Wood C.W., Tracy P.W., Reeves D.W., and Edmisten K.L., 1992. Determination of cotton nitrogen status with a hand-held chlorophyll meter. J. Plant Nutrient, 15, 1435-1448. 